\title{
Theoretical Basis, Influencing Factors and Strategies of National Audit Professionalism
}

\author{
Xumeng Liu \\ Government Audit School of Nanjing Audit University \\ Nanjing Audit University \\ Nanjing, China
}

\begin{abstract}
Firstly, the paper summarizes the connotation, significance and necessary conditions of national audit professionalization. Then the paper concludes the theory of reputation, the theory of professional competence, the theory of human capital and the theory of state governance, and expounds it as the theoretical basis of national audit professionalization. This paper analyzes the influencing factors that hinder and promote the professionalism of national auditing in China. At last, the paper designs a set of concrete strategies to improve the professionalization of national auditing, and discusses the ways and strategies of the national audit professionalization from three aspects: principle, system and supporting measure.
\end{abstract}

Keywords—national audit; professionalism; implementation strategy

\section{INTRODUCTION}

National audit professionalism is the only way to realize the further development of China national audit, and it is also the necessary requirement to make national audit play an important role in national governance system. The path of national audit professionalism is a process that traverses the construction of a sound system and environment, the national audit team has been trained to become the necessary authority, a group with a sound audit work philosophy, technical methods, a high degree of professionalism and professional quality. National audit professionalism construction is a breakthrough in the development of the current national audit bottleneck, but also to build the future of the national audit team's distinctive banner. With the rapid development of the national audit and the deepening of the reform of the audit system, the realization of the professionalism of the national audit has become one of the important topics to be discussed in the theory and practice of the national audit.

\section{THEORETICAL ANALYSIS OF NATIONAL AUDIT PROFESSIONALISM}

\section{A. The Intention, Significance and Essential Condition of National Audit Professionalism}

Many specialists had given the concept and condition of this topic. (Zheng Y. T., 2002) considered that the professionalism is the state that people finish their social task or team task accurately and professionally. H. Wilensky (1964) thought that the necessary elements of professionalism are enough practitioners, place for occupation training, profession organization and profession morality system

As a special administrative work, the professionalism has its distinct characteristics.

Firstly, employees of national audit office are civil servants in essence. They don' $t$ have interest relationship with the office be audited. They need undertake more social responsibilities too. The monitor function of national audit can prevent public authorities from abusing and can promote the law-based administration of government. It undoubtedly requires the independent and objective status, thorough management system and bigger voice on national level of national audit office.

Secondly, the work of national audit belongs to technical professional behavior, it need professional employees and the use of various kinds of audit methods. This background requires progress of audit technology and progress of audit workers' abilities.

At last, the national professionalism is also embodied in political accomplishment, moral cultivation and interpersonal communication ability of national auditors.

By means of summary and analysis, the meaning of intention of national audit professionalism can summarize as follows:

- The organization structure and system of national office ensure that they can fulfill power to supervise through auditing according to law independently.

- The national auditors have the necessary audit abilities, moral level and well professional attitude.

Under the background of the new economic norm, professionalism is the new challenge and request to national audit. Its significance has the following 3 points

- National audit professionalism improves the efficiency of national audit, it is necessary because of the urgent demand under the new economy environment. 
- National audit professionalism ensures the quality and effect of national audit, and ensures the economy running smoothly.

- National audit professionalism maintains the social reputation of audit office, and improves its social status.

Reference to professional theory and together with the present situation of national audit, 4 essential conditions are most important on the implementation path of national audit professionalism:

- The number, professional competence and professional attitude meet the requirement of professionalism.

- On-the-job training and education to auditors is up to standard of the requirement of professionalism.

- Perfect security on law and system level to ensure the audit office can perform audit work in accordance with the professional demands.

- There are professional organizations or industry associations. They set standards of professionalism and make evaluation on auditors.

\section{B. Theoretical Basis of National Audit Professionalism}

1) National governance theory: Basic meaning of national governance is: Under the background of socialism with Chinese characteristics, the communist party lead people and govern the country with science, democracy, legitimacy and effectiveness (Wang P. Q.,2014). National audit office monitors the financial revenue and expenditure of fiscal authority based on principles of authenticity legitimacy and profitability. From the deep level reason, the emergence and development of the national audit result from national governance, the demand of national governance determines the generation of the national audit, the goal of national governance determines the direction of the national audit (Liu J. Y., 2012). As an important regulatory system of national governance system, national audit improves the process of national governance by functions of supervision, evaluation and verification. At the same time, the demand of national governance determines the necessity and orientation of the national audit. Under the goal of national governance, it becomes a more and more critical task that to construct the national audit professionalism.

In the process of deepening national governance, it produced the requirements of audit full coverage. It means that national audit office should audit all the departments which manage, distribute or use the public funds, the stateowned assets and the state-owned resources and audit all the situation of economic responsibilities belong to leading cadres of Party and government and leading cadres of stateowned enterprises. Under the background of audit full coverage, objects and business contents of national audit becomes more and more complicated. All audit offices are facing troubles of limited time, heavy tasks and lack of employees. In this environment, national audit professionalism becomes more and more important. By improving the professional quality of auditors, improving the national audit system and optimizing audit business process, more and more professional national audit can provide security to expanding national audit business.

2) Reputation theory: Reputation means honor, fame, and credit of individuals or organizations. In economics, reputation theory concludes that the reason of individuals or organizations establish and maintain reputation between people with information asymmetry, and also concludes how reputation play a role on incent stimulating them. This theory includes 2 sides: Analysis on individuals is called individual reputation theory; Analysis on construction and protection of organizations called organization reputation theory or company reputation theory. In the research of national audit, reputation theory mainly refers to organization theory.

Organization reputation is the integrated embodiment of all the actions and results belonged to companies. It also reflects the ability of companies' value delivery to stakeholders (Fombrun \& Rindova, 1996). Organization reputation can measure companies' status in relationship between their employees and stakeholders. Fombrun et al. (1997) find several attributes of Organization reputation by reading references:

- It makes clear companies' status in their areas

- It is the external performance of staffs' internal evaluation to companies

- It is born from companies' trajectory and resources they owned. It can also be one kind of the action barriers that can change both actions of company and its competitors;

- It is the comprehensiveness of evaluation to companies from different objects;

- It can simplify the construction of companies' performance to offer help observing complex market environment;

- It reflects two different dimensionalities to evaluate efficiency of companies-economic benefit and social benefit.

Cravens et al. (2003) quantize the organization reputation and make it reflected in the financial reports. They evaluate reputation through 3 aspects. At first, they divide organization reputation into 9 parts: products and service, employees, external relationship without consumers, innovation, value creation, funds, strategies, cultural and intangible liabilities. Then, they design weight of each part: Products and services are highest that account for 30\% 60, secondly is employees, external relationship and innovation that occupy $20 \%$, cultural and intangible liabilities are lowest that close to $0 \%$. At last, by the work did before, they grade all the companies and divide them into 3 levels. 
In the system of national audit reputation, it not only clear out national office's social responsibilities and social evaluation, but also decide what position that national audit play role in national governance. In reputation attributes of national audit, audit service and national auditors occupy the most important position. It means that we should improve both quality of national audit business and national auditors to realize national audit professionalism. It is also the significance approach to improve the reputation of national office.

3) Human capital theory: Human capital theory originates from research on western economy. It compares human capital as the more important capital than material capital. It also emphasizes that we can enhance the quality of human capital and get profit by reasonable investment

The first expert that discuss on human capital theory is A. Smith (1964), the famous representative of classical economics. He expounds the concept of this theory in his book An Inquiry into the Nature and Causes of the Wealth of Nations. He put forward that cost on study and education in school or in work is the capital congealed on people. Theodore W. Schultz (1960) concludes that human capital mainly refers to people's abilities of wok came from their own abilities and professional skills. It is reason of investment with rare resources. In his book Investment of Human Capital, he divides investment of human capital to some scopes:

- Health care and daily cost;

- On-the-job training and regular college education

- External study project and technology promotion

- Removal because of oneself, family or job opportunities;

Theodore W. Schultz is also one of the most important representative personages of human capital theory.

Under the theory of human capital, as the special human capital, national auditors have much more value than material capital of audit. And it is the source to make national audit develop quickly and thoroughly. Investment on auditors is the concrete form of embodiment of national audit professionalism. At the same time, we should optimize the construction of investment on them: take education and healthcare investment as the main investment, other means are supplemented. Methods like motivator can also be used to improve the result and quality of investment.

4) Professional competence theory: McClelland (1973) concludes that competence is people's knowledge, skills, abilities or motivation. These peculiarities are similar with work efficiency of work and other important achievements. Boyatzis (1982) put forward that the final manifestation of work is decided by the employee's motivation, psychological traits, skills, social character and knowledge level. Spencer (1993) points out that professional competence can be an element of evaluation to forecast people's professional performance in the future before they begin to work. It mainly includes people's motivation, specialty background, characteristics of images, professional attitude, value, skills need to grasp, etc.

On the whole, professional competence of national auditors can be understood as their potential peculiarities to get excellent achievement in the future. It includes national auditors' professional attitude, social position, professional motivation, education and specialty background, psychological situation, moral traits, skill level, etc.

Based on iceberg theory pointed out by S. Freud et al., McClelland (1973) create iceberg model by his research result. He divides workers' peculiarities to dominance and recessivity. On an iceberg, the part that above water is the dominant peculiarity, the part under water is the recessive peculiarity. In actuality, dominant peculiarity includes some basic conditions such as knowledge, skill, etc. Not like recessive peculiarity, it can be observed easily. Recessive peculiarity plays a decisive role in performance of employees. It includes motivation, values, self-knowledge, etc.

In the construction of national auditors, knowledge and skills of audit is basic but personal pursuit and social responsibility more critical. It is necessary for us not only to pay attention on dominant peculiarities such as education and knowledge background, but also consider recessive peculiarities such as values, social responsibility, career responsibility and identify, etc. comprehensively.

5) Influence of four theories on national audit professionalism: The four theories above play a role of support and promotion to national audit professionalism.

At first, demand of national governance determines the necessity and orientation of the national audit. National audit need serve national governance and need meet the requirement of national governance. It requires that national audit should realize both professionalism of auditors, sanity of audit system and standardization of audit process.

Secondly, reputation theory explains the vital function to national audit from organization reputation. It also explains that construction of national audit professionalism need pays more attention on important sides such as service quality and employee quality. These sides influence organization reputation and social evaluation of national audit office.

Thirdly, human capital theory looks on national auditors as a kind of special capital. It shows the vital meaning of investing in national auditors. At the same time, it points out the main directions of investment: take education and healthcare investment as the main investment, other means such as motivation is supplemented. On the whole, investment of human capital can be considered from on-thejob training, follow-up education, and live environment, national cultural and professional motivation.

At last, professional competence theory establishes system of national auditors' professional skills. Under the vision of it, abilities of national auditors are divided into 2 aspects: dominant and recessive. It provides some specific indicators to select, cultivate and evaluate national auditors in "Fig. 1". 


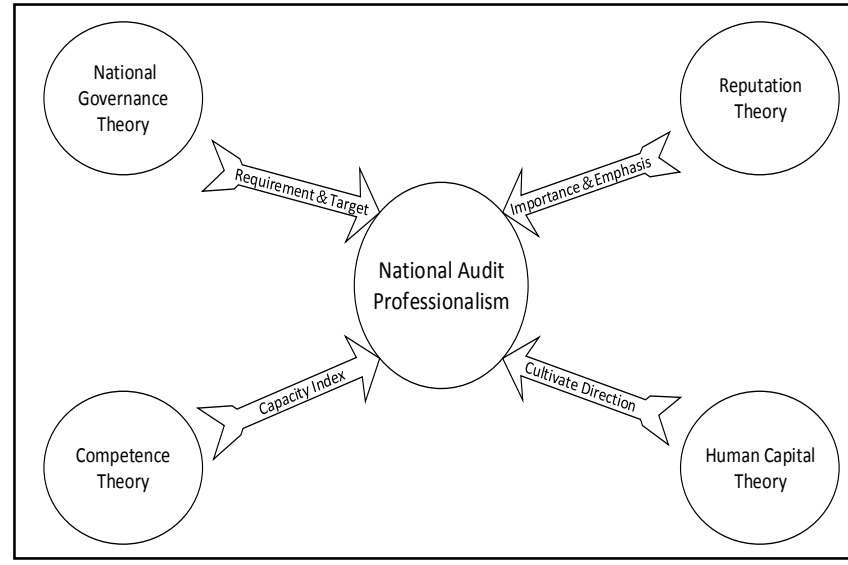

Fig. 1. Influence of four theories on national audit professionalism.

\section{INFLUENCING FACTORS OF NATIONAL AUDIT PROFESSIONALISM}

\section{A. Influencing Factors that Hinder Development of National Audit Professionalism}

1) Influencing factors of selection mechanism: As a special kind of civil servants, national auditors accept delegation of nation and exercise the auditing supervision power independently. With the higher and higher request of national audit quality, the selection method should be more and more stringent. But from the present situation of our country, the selection of national auditors is the same as other normal civil servants. It is done in 2 main ways:

a) By civil servants exam: National audit office selects people with higher comprehensive quality by unified civil servants exam. These auditors have not bad comprehensive quality and bachelor degree and above through the open recruitment exam. But audit professional knowledge is always not contained in the civil servants exam. We can't make sure that people with high exam scores suit to national audit work. And national audit office always requires the specialty background of economics and management. It makes national auditors harder and harder to adapt the trend of diversified development of national audit work.

b) By selection: Part of national auditors come from other units such as enterprises and public institutions. They always come here by lateral move and rarely consider their educational background. It is hard to make sure that everyone national auditors have necessary specialty literacy to do audit work.

2) Influencing factors of structure and quantity of auditors: As the increase of national audit tasks, there are some hysteresis phenomenon appearing because of the knowledge and personal structure of national auditors. It mainly reflects in 2 aspects:

a) Lack of people: As the new request of national audit full coverage, national office is always understaffed when dealing with more and more audit task. Some office second auditors from other office to complete audit task and it makes a vicious circle that other office face the problem of the lack of auditors again. This phenomenon hurt the quality and development of national audit professionalism.

b) Ability limit: Knowledge and educational background of national auditors can't meet the requirement of national audit work under the new normal background. It has to do with historical issues of our country. Chins begins to promote the regulations of civil servants exam when Interim Regulations of Civil Servants issued in1993. In national audit group at present, many of them come from army and other units. National audit is not only the simple check on financial fund, but also the comprehension on policy and the utilization of technology and analysis method. National auditors will hardly finish the target of national audit task if they don't have the good knowledge structure and ability to quick study.

3) Influencing factors of national audit system and independence: Independence is the soul of national audit. It influences the quality and effect of national audit directly. Constitution and Audit Law give the authority of independent audit to national audit office. But under the current system, national office always serves the government to do supervision work but not supervise independently from the government. Shortcomings of it show as follows:

a) Organization form of national office have limits: Government auditing agency implement dual leadership: Its administrative relations belong to the local government and it carry out audit work leaded by both national office and local government (Cheng Y. Q., 2015). Appointment and removal of local auditing agency's leading group need ask opinions from superior auditing agency but don't need ask for their permission.

b) There is boundedness in function and power of national office: National audit office can only give some economic punishment to illegal departments. National audit office always moves them to discipline inspection commission to give them administrative penalty. This result is lack of audit authority.

With the lack of independence and authority, work of national audit is limited to some extent. It hinders the efficiency of auditing supervision and the process of national audit professionalism.

\section{B. Influencing Factors that Promote Development of National Audit Professionalism}

1) Experience from civil audit and internal audit: On the path of national audit professionalism, we can complete the audit task more quickly by borrow the experience from civil audit or internal audit. Following are the main points:

a) Guild system: IIA and CICPA are 2 good examples as the guild pattern. They are founded to manage their members and conduct exams \& assessment to checkout members' qualification to finish their work. In national audit 
system, China Audit Society is founded to research the theory and practice of audit. But it is not the guild of national audit in its true sense. At first, China Audit Society put much attention but is lack of entry conditions and unified standard to members. Then, China Audit Society doesn't have its own qualification certificate and evaluation system. Once more, China Audit Society doesn't only study on national audit, but also research on civil audit and internal audit. At last, China Audit Society train and educate its members without coerciveness. Refer to the experience of other audit subjects, a professional guild can be considered built in national audit system.

b) Qualification and certificate system: It put forward high request of qualification and certificate to internal auditors in UK and US. It needs not only the attestation of educational background and morality, but also detailed test score of CIA. The certificate system provides the basis to choose talents of internal audit and guarantee the high quality of internal auditors. The selection of national auditors just follows the method in selection of civil servants with hardly any request of professional qualifications. At the same time, there is no uniform certificate in national audit system.

c) Risk control system: Audit risk in civil audit means the loss to organization made from CPA. It includes the wrong audit opinion and the business failure of customers (Wang F. H.,2006). In control system of civil audit risk, following are several main approaches:

- Practice abide by independent auditing standards of CPA

- Execute the quality check system of accounting firm

- Consider the audit risk when choose customers

- Deal with the relationship between significance and audit risk correctly

The risk control system of national audit is comparatively perfect but it still can use reference from civil audit. At first, national audit office can design a set of operational guidelines aimed at different purpose in national audit work. Then, based on the independence of national audit, it can take turns of auditors according to a fixed schedule. At last, according to the three-review system in civil audit, national audit office can carry out check system more macroscopically on audit plan and arrangement.

2) Development of master of auditing and research on audit science: To adapt the keen demand of top talents in audit and the development of economic society, government set up the master of auditing (MAud) degree. The purpose of MAud is to cultivate the practical talents with well political accomplishment, high moral level and ability to solve actual audit problems. With the cultivation mechanism becomes better and better, channels of national audit office to find talents will be more abundant. It also suits the requirement of national audit professionalism.
At the meeting of national audit construction (Chi G. H.,2016), many experts pointed out that it is necessary to build audit as the first-level discipline and promote the effect of audit education in national audit. The appreciation from universities to national audit has important meanings:

- It can cultivate more audit talents for national office to solve the contradiction between increasing number of audit tasks and the lack of auditors.

- It can promote more and more researchers to devote in national audit research and create good basis on formulation of audit system and innovation of audit skills.

3) The faded thought of official standard: In our traditional society, thought of official standard had always been there. In this potential thought, the superior has absolute power to the subordinate. It can make national auditors dare not to do some audit work and weaken the independence of national audit. But this phenomenon fades away now mainly because of:

- Construction of society with rule of law

- Loss of officers' privilege

- Development of social value

Under the background of faded thought of official standard, national audit office get positive benefits as follows:

- National auditors won't think themselves as “jack-inoffice" and will put more attention on practical audit work. Although national office is an office that in need of authority. But the good or bad performances of audit work mainly depend on specialized knowledge auditors can use in practice.

- The audit object of national office is also government offices. In the past, a part of offices uses their authority in hands to hinder the audit work. As the thought of official standard fades away, this phenomenon is becoming less. It makes national auditors doing their work more smoothly.

- To the public, civil servants are not a work that too high to reach and they can give their advice and comment to national auditors in a more objective view.

\section{StRATEgIES OF NATIONAL AUdit PROFESSIONALISM}

\section{A. Basic Principles}

It need follow 3 basic principles to ensure the strategies designed can be available to the process of national audit professionalism.

1) Promote quality of auditors and complete management system: On the path to build national audit professionalism, national auditor is the core content. On the whole, the construction of national audit professionalism can't success without an auditors group with professional quality, enthusiasm to audit work, supreme morality and 
adaption to every audit tasks. There are to aspects in build the talents group of national audit, one is how to choose and cultivate people another is how to manage and make use of people. To promote quality auditors and complete management system is one of the basic principle of national audit professionalism.

2) Standardize workflow of audit work and elevate quality of audit business: Owning the professional national auditors is not equal to owning the professionalism of national audit. High quality of national business is also the key to it. To promote the quality of national audit business, one is to make a standard to audit work, another is to enrich the methods to control the quality of audit business.

3) Optimize national audit system and serve the national governance: National audit is the instrument of national governance and the national audit professionalism is the only way which must be passed to develop national audit. A wholesome national audit system is the footstone of the realization of national audit professionalism. It is important to ensure that national office can execute audit work independently and can maintain the objectivity and authority of national audit.

\section{B. System Designing}

1) System of National Audit Guild: According to the analysis before, a complete guild is significant to national audit professionalism. Expect some administrators, all national auditors should pass the qualification test and join in the National Audit Guild. National Audit Guild should be established with the following functions:

- Asses and evaluate the level of professionalism of national auditors

- Conclude the criterion and rules of national audit works and supervise the implementation

- Organize the unified examination of national audit knowledge and issue the qualification certificates

- Organize the training and education to national auditors and hold the seminar regularly

- Conduct the research on national audit theories and provide technical support to national office

2) System of admittance and quit: To solve the situation of national auditors with various educational levels, admittance to national office should be completed to make the new national auditors fit the requirement of national audit. The following methods can be used:

a) Classified exam: The administrators and professional auditors should be recruited respectively. National office can improve the application condition of professional auditors to ensure that people with various specialty background (Auditing, Accounting, Economics, Computer and Engineering) have special way to join the recruitment. And it is necessary to improve the method of exam to make it can inspect whether candidates have requisite skills of national audit or not. b) Step-by-step selection: The superior auditing bodies can select people from subordinate offices. National audit office can also select talents from other government departments according to their work experience and educational background.

c) Social recruitment: National audit office should develop channels to select special talents from society and enhance openness of national audit groups. Social talents can be arranged by appointment system to different audit departments based on their working background. National office should keep an eye on their working attitude and career potential too.

It is also important to build the quit mechanism in process of national audit professionalism. The job of national auditors should not be unshakable. It should break the "lifelong tenure" now by the law of survival of the fittest. At the same time, incentive mechanism should be built to create effective competition in office and to improve impetus of national auditors.

3) System of vocational training: According to the human capital theory, investment to education is the priority among priorities. National audit is in a certain condition of dynamic development and the training to national auditors should advance with the times to adapt the changeful situation of national audit. To complete the vocational training system can be done in 3 ways:

a) Diversification way of training: The style of training can't only be limited in seminar and college course but also need use some social methods as references (online course, external experts or knowledge contest).

b) Pertinence of training: According to different education or work background and their working areas, national office can formulate different training plan to make every national auditor can get comprehensive audit knowledge and the ability to deal with the facing audit problems at the same time.

c) Other aspects of training: The professional training of national auditors can't only stay on the lay of technical skills, but also need cultivate their emotion quotient, interpersonal skills and political accomplishment.

4) System of quality control: Based on reputation theory, quality of audit service occupies the most important position in national reputation system. It is necessary to build a quality control system and standard business process to meet the request of national audit professionalism. Specific practices are showing as follows:

a) Optimize the process of audit business: National office can generally manage the audit process by 4 aspects: audit plan, audit practice, audit re-check and audit result trace. The professional auditors, administrators and disciplinary inspectors should classify their own responsibilities.

b) Strengthen the check and evaluate: National audit office should check the business quality of their departments, agencies and subordinate bodies. The main check objects 
include set of audit quality management system and present audit tasks. At the annual evaluation of national audit, it is important to set the reasonable weight in evaluate system and to build the externa supervision and publicity.

c) Build the Accountability Mechanisms: The accountability should definitize the scope, property and subject. The audit responsibilities can be divided to procedure responsibility, position responsibility, rule responsibility and law responsibility. National should choose different processing means depend on the order of severity. National should also analyses the reason of incidents and the influences on national audit work.

\section{Supporting Measure}

1) Culture guarantee: Under the competence theory, the professional skill of national auditors is only the dominant peculiarity and can be observed easily. Recessive peculiarity like career goal and morality play a decisive role in performance of auditors. To create an excellent audit culture can optimize their professional behavior, improve their career attitude and enhance the national audit working quality to develop the process of national audit professionalism. The culture guarantee can be considered by 3 aspects:

a) Based on material culture: The material culture of national audit includes every aspect like workplace, audit technology and salaries. In the design of material culture, the basic quality of life should be considered firstly to ensure the national auditors can enjoy the necessary welfare and the reasonable salary. Then the selection of working environment and office facility need meet the basic requirement and emerge the specialty of national audit at the same time. At last, national audit office can emphasize the advanced and scientific culture characteristic of national audit by researching and developing on new audit technologies.

b) Appreciate system culture: National office need use advanced audit system as main idea combined with organization structure, status and auditing status of audit bodies to build the own system culture of national audit. It can deepen the national auditors' thought of their duties and organization status to command them easily.

c) Mental culture: Mental culture is the core of the built of national audit culture. It is the coalition of value orientation, moral rule and spiritual pursuit that formed in daily practice. National audit office can structure the mental culture system synthetically by the aspects of dedicated, law-abiding, independent, just, honest, dedicated, rigorous and progressive.

2) Organization guarantee: The organization guarantee need be established to ensure that achievement of national audit professionalism can play a role in the process of national governance. The organization guarantee means the guarantee of independence and voice of national audit office. It can be built in 3 aspects: a) Vertical management: At present, government auditing agency implement dual leadership and it is the harm to auditing independence. To bring vertical management system into operation can reduce the intervention to auditing work from local government and can re-collocate and integrate the audit resources between superior and subordinate auditing agencies.

b) Unified management of people and property: To build the unified management of people and property can get rid of control from local government and can form the system of circulation of talent to easily make the overall arrangement of all national audit tasks. At the same time, unified management of people and property is also the supplement and extension of vertical management system.

c) Enhance authority: National office can endow authority and voice to national audit from the legal system. It can consider to appropriately increase authorities on judgement and direct disposal expect for the basic authorities on check and suggestion. It makes the more authoritative national audit office and the brighter and clearer specialty of national audit professionalism.

\section{CONCLUSION}

National audit professionalism is the necessary requirement to make national audit play an important role in national governance system. This paper points out that the current situations and influencing factors of national audit professionalism in selection mechanism, structure and quantity of auditors, national audit system and independence and correlational research by study on five basic theories of national audit professionalism. This paper puts forward several strategies to promote national audit professionalism process. Specifically, it can set up system of national audit guild, system of admittance and quit, system of vocational training and system of quality control and establish culture guarantee and organization guarantee to convoy the development of national audit professionalism.

\section{ACKNOWLEDGMENT}

I want to take this chance to thanks to my tutor Professor Huang. In the process of composing this paper, he gives me many academic and constructive advices, and helps me to correct my paper.

\section{REFERENCES}

[1] McClelland D C. Testing for competence rather than for "intelligence". [J]. American Psychologist,1973,28(1).

[2] Spencer L.M., \&Spencer.S.M. Competence at work: Models for superior performance. [M] New York: John Wiley \& Sons, Inc., 1993 , P.9-11.

[3] IFAC.Competence Requirements for Audit Professionals(Draft),www.ifac.org,2005.

[4] Fombrun, C.J., and Rindova, V.. Who's Tops and Who Decides? The Social Construction of Corporate Reputations [R]. New York University, Stern School of Business, Working Paper, 1996.

[5] Fombrun, C.J.,and Riel, C.V..The Reputational Landscape[J].Corporate Reputation Review, 1997,(1): 5- 13. 
[6] Boyatzis R E. The competent manager: a model for effective performance. New York: John Wiley \& Sons, 1982

[7] Cravens, K., et. al.. The Reputation Index: Measuring and Managing Corporate Reputation [J]. European Management Journal, 2003, 21(2):201-212.

[8] AlbertL.Nagy, WilliamJ.Cenker. Internal Audit Professionalism and Section 404 Compliance: The View of Chief Audit Executives from Northeast Ohio[J]. International Journal ofAuditing, 2007,11(1). 